\title{
FIRE DESIGN OF CLT IN EUROPE
}

\author{
Birgit Östman*
}

Senior Advisor

Linneaus University

Växjö, Sweden

E-mail: birgit.ostman@lnu.se

\section{Joachim Schmid}

Doctoral Candidate

E-mail: schmid@ibk.baug.ethz.ch

\section{Michael Klippel}

Senior Scientist

ETH Zürich

Zürich, Switzerland

E-mail: klippel@ibk.baug.ethz.ch

\author{
Alar Just \\ Professor \\ TUT Tallinn University of Technology \\ Tallinn, Estonia \\ RISE Technical Research Institutes of Sweden \\ Stockholm, Sweden \\ E-mails: alar.just@ttu.ee, alar.just@ri.se \\ Norman Werther \\ Research Associate \\ Technical University of Munich \\ Munich, Germany \\ E-mail: n.werther@tum.de \\ Daniel Brandon \\ Researcher \\ RISE Technical Research Institutes of Sweden \\ Borås, Sweden \\ E-mail: daniel.brandon@ri.se
}

(Received August 2017)

\begin{abstract}
The fire safety design of cross-laminated timber (CLT or X-Lam) in Europe is governed by the Construction Products Regulation and its essential requirements, as for all other building products. These requirements are mandatory, to be used in all European countries. They include classification systems for reaction to fire of building products, fire resistance of building elements, and structural Eurocodes. The reaction-to-fire performance of CLT in accordance with the European classification system is specified. Higher classes can be reached by chemical treatments, but the durability of the reaction-to-fire performance needs to be fulfilled according to a new European system. The fire resistance design of CLT building elements is not included in Eurocode 5, the structural Eurocode for timber, but can be either tested according to European standards or calculated by using design methods being developed recently. This article provides information about both reaction to fire and fire resistance of CLT in Europe.
\end{abstract}

\footnotetext{
* Corresponding author
} 
Furthermore, the importance of proper detailing in building design and in practice is stressed. Finally, performance-based design is introduced and some further research needs suggested.

Keywords: Building fires, charring, reaction to fire, fire resistance, detailing, performance-based design.

\section{INTRODUCTION}

Cross-laminated timber (CLT) is an increasingly used engineered wood product with its origin in central Europe in the late 1990s. It has had a very rapid development and reached interest and acceptance in all Europe, partly because of its robustness and ease of use. It is now used in many building projects with medium-rise buildings and several high-rise buildings are being planned. A European product standard (prEN 16351) is planned to be approved earliest in 2019.

However, the fire issues are being discussed frequently and concerns have been raised about both life and property safety. This article summarizes the present situation in Europe with regard to the fire design of CLT. The following topics are covered:

- Reaction-to-fire performance of CLT

- Load bearing capacity of CLT in fire

- Protection of CLT members by claddings

- Fire safe detailing of CLT structures

- Performance-based design of CLT.

The article starts with a brief overview of the European system for construction products and ends with the need of further research in the area of fire design of CLT.

\section{EUROPEAN SYSTEM FOR CONSTRUCTION PRODUCTS}

The European system for fire safety in buildings includes product standards, performance classes in case of fire, and testing and calculation standards for fire performance. The European standards for fire safety in buildings are concerned mainly with harmonized methods for verification of fire performance.

\section{Essential Requirements in Construction Products Regulation}

Common European performance-based requirements for construction products were introduced by the Construction Products Directive (CPD), which was adopted in 1988 and replaced by the Construction
Products Regulation (CPR 2013). CPR contains seven essential requirements, one of which is fire safety. The CPR requirements on fire safety are that structures must be designed and built such that in the case of fire:

- The load bearing capacity can be assumed to be maintained for a specific period of time;

- the generation and spread of fire and smoke is limited;

- the spread of fire to neighbouring structures is limited;

- occupants can leave the building or be rescued by other means; and

- the safety of rescue teams is taken into consideration.

These essential requirements are implemented and detailed in European standards (see Fig 1). The European system has to be used in all European countries, but the requirement levels in national building codes may vary.

\section{CLT Fire Performance}

Limitations of the reaction-to-fire class of surface linings are required in most national building codes and may not be fulfilled by wooden linings. Sprinklers may be used as an alternative design solution. But in the fully developed fire, ie after flashover in a room, the performance of both the load bearing and separating structures is important to limit the fire to the room of origin. High levels for separating and load bearing capacities can be achieved for CLT structures.

\section{REACTION-TO-FIRE PERFORMANCE}

\section{Harmonization of Classification Systems for Reaction-to-Fire Performance of Building Products}

Reaction to fire involves the response from materials to an initial fire attack and includes properties 


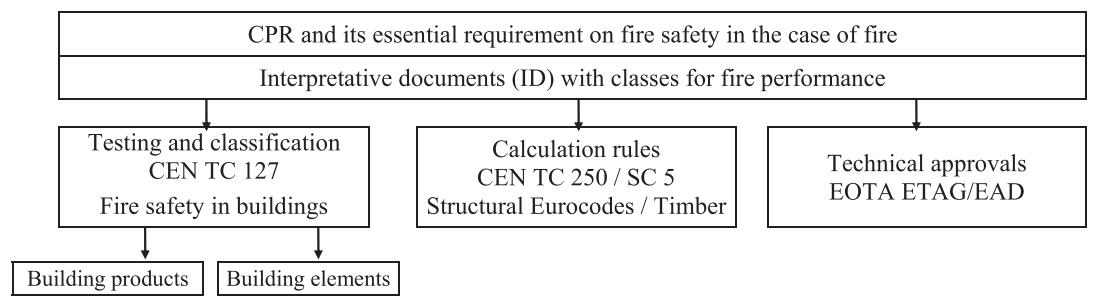

Figure 1. Systems for European fire standards for building products.

such as time to ignition, flame spread, heat release rate, and smoke production.

A European classification system (EN 13501-1) for the reaction-to-fire properties of building construction products was introduced in 2000. The system is often referred to as the Euroclass system and consists of two subsystems: one for construction products excluding floorings, ie mainly wall and ceiling surface linings, see Table 1, and another similar system for floorings. Both subsystems have classes A-F of which classes A1 and A2 are for noncombustible products. Additional classes are defined for smoke, s1-s3, and burning droplets, d0d2. This European system has replaced the earlier national classification systems, aiming to decrease the number of obstacles for international trading of products and services.

The European classification system for reactionto-fire performance is based on a set of $\mathrm{EN}$ standards for different test methods. Three test methods are used for determining the classes of combustible building products (see Fig 2). For noncombustible products, additional fire test methods are used.

\section{Reaction-to-Fire Performance of Wood Products}

Products with known and stable performance may be classified as groups according to an initiative from the European Commission (Construct 2004). This is a possibility for wood products that have a fairly predictive fire performance. Properties such as density, thickness, joints, and type of end use application may influence the classification. The procedure is called classification without further testing (CWFT) and is a list of generic products, not a list of proprietary products (Östman and Mikkola 2010).

The CWFT approach has recently been applied also to CLT (Commission Delegated Regulation 2017), which is classified as D-s2,d0 or $\mathrm{D}_{\mathrm{fl}}-\mathrm{s} 1$ (for floorings) for thicknesses and densities over certain limits. These data have been approved by the European Commission and published in their Official Journal.

Table 1. Overview of the European reaction-to-fire classes for building products used as wall and ceiling linings.

\begin{tabular}{|c|c|c|c|c|c|c|c|}
\hline \multirow{2}{*}{$\begin{array}{l}\text { Euro } \\
\text { class }\end{array}$} & \multirow[b]{2}{*}{ Smoke class } & \multirow[b]{2}{*}{ Burning droplets class } & \multicolumn{3}{|c|}{ Requirements according to } & \multirow{2}{*}{$\frac{\text { FIGRA }}{\mathrm{W} / \mathrm{s}}$} & \multirow[b]{2}{*}{ Typical products } \\
\hline & & & Non comb & SBI Test & Small flame Test & & \\
\hline A1 & - & - & $\mathrm{x}$ & - & - & - & Stone and concrete \\
\hline $\mathrm{A} 2$ & $\mathrm{~s} 1, \mathrm{~s} 2$, or $\mathrm{s} 3$ & $\mathrm{~d} 0, \mathrm{~d} 1$, or $\mathrm{d} 2$ & $\mathrm{x}$ & $\mathrm{x}$ & - & $\leq 120$ & $\begin{array}{l}\text { Gypsum boards (thin paper) and } \\
\text { mineral wool }\end{array}$ \\
\hline B & $\mathrm{s} 1, \mathrm{~s} 2$, or $\mathrm{s} 3$ & $\mathrm{~d} 0, \mathrm{~d} 1$, or $\mathrm{d} 2$ & - & $\mathrm{x}$ & $\mathrm{x}$ & $\leq 120$ & $\begin{array}{l}\text { Gypsum boards (thick paper) } \\
\text { and fire-retardant wood }\end{array}$ \\
\hline $\mathrm{C}$ & $\mathrm{s} 1, \mathrm{~s} 2$, or $\mathrm{s} 3$ & $\mathrm{~d} 0, \mathrm{~d} 1$, or $\mathrm{d} 2$ & - & $\mathrm{x}$ & $\mathrm{x}$ & $\leq 250$ & Coverings on gypsum boards \\
\hline D & $\mathrm{s} 1, \mathrm{~s} 2$, or $\mathrm{s} 3$ & $\mathrm{~d} 0, \mathrm{~d} 1$, or $\mathrm{d} 2$ & - & $\mathrm{x}$ & $\mathrm{x}$ & $\leq 750$ & Wood and wood-based panels \\
\hline $\mathrm{E}$ & - & - or $\mathrm{d} 2$ & - & - & $\mathrm{x}$ & - & Some synthetic polymers \\
\hline $\mathrm{F}$ & - & - & - & - & - & - & Fails to fulfill class E criteria \\
\hline
\end{tabular}

SBI, single burning item, main test for the reaction-to-fire classes for building products, EN 13823; FIGRA, fire growth rate, main parameter for the main fire class according to the SBI Test. 

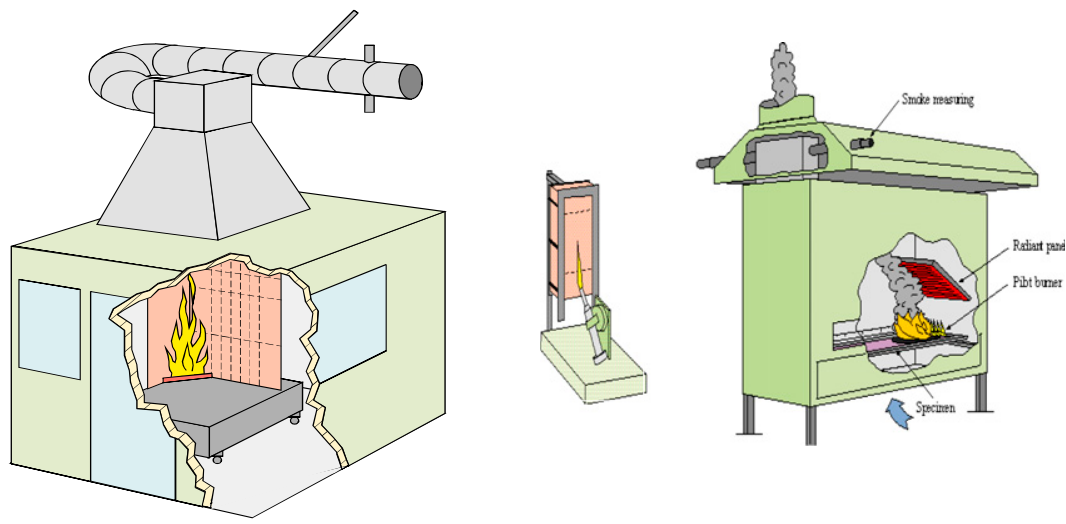

Figure 2. Three main test methods for the reaction-to-fire performance relevant for wood products: the SBI Test (Single Burning Item Test), EN 13823; Small Flame Test, EN ISO 11925-2 and; the Radiant Panel Test for floorings, EN ISO 9239-1.

\section{Fire-Retardant Treatments for Wood Products}

It is relatively easy to obtain an improved fire performance of wood products. Most existing fire retardants (FRs) are effective in reducing different reaction-to-fire parameters. The highest European and national fire classifications for combustible products can be reached (Östman et al 2010). But for the fully developed fire, the influence is minor (Nussbaum 1988). One exception is intumescent paints that may delay the time for start of charring and, thus, increase the fire resistance of timber structures. In any case, FRs cannot make wood noncombustible.

However, the excellent fire performance of the virgin FR wood products may degrade over time, especially in outdoor applications. When exposed to high humidity, the FR chemicals may migrate in the wood toward the surface and may ultimately be leached out. This problem has been known for a long time in the United States and the United Kingdom, but is not so well known in the rest of Europe. A literature review (Östman et al 2001) and studies on exterior exposure during up to $10 \mathrm{yr}$ (LeVan et al 1986; Östman et al 2017) have been published.

A European system with durability of reaction-tofire performance classes has been developed to guide the potential users to find suitable FR treated wood products (EN 16755 2017). The system is based on a North American system and a previous Nordic system. It consists of a classification system for the properties over time of FRT wood and suitable test procedures.

\section{LOAD BEARING CAPACITY OF FIRE-EXPOSED CLT}

Fire design of timber structures is based on standard fire temperature design, ie predicting the decrease in the load bearing capacity when the structural element, ie a wall or a floor element, is exposed to standard fire. The standard fire time-temperature normally considers a duration of up to $120 \mathrm{~min}$ and covers a range of incident radiant heat fluxes between 0 and $175 \mathrm{~kW} / \mathrm{m}^{2}$ depending on the duration of exposure (Babrauskas 2005; Schmid et al 2017a). In tests using compartments made from solid wood, it was shown that the temperature peak is not influenced by the additional fire load because of the combustible structure, but effects on the exterior were observed (Hakkarainen 2002; McGregor 2013; Medina Hevia 2014). Following the design of timber members given in Eurocode (EN 1995-1-2), the load bearing behavior of timber members in general and CLT in specific is to be determined based on their behavior in standard fire. Design methods for CLT are available (Östman et al 2010).

The load bearing capacity of timber members in fire can be determined using advanced methods, ie finite element or other numerical calculations, 
or simplified methods. The effective cross-section method allows the simplified design by following a two-step approach, where (1) the residual cross section is determined and (2) the load bearing capacity of this residual cross section is calculated. Both steps are presented in the literature, eg (Klippel et al 2016), and some important background information and CLT-specific behavior concerning both steps are presented in the following paragraphs.

\section{Charring Behavior of Timber with Respect to CLT Structure}

The charring behavior of CLT may be different from the charring of homogenous timber panels because of the layered, glued composition and joints between the timber boards that can lead locally to increased charring. Many fire tests using standard fire exposure on CLT wall and floor elements have been performed in recent years and the charring behavior documented (Klippel et al 2016). The charring behavior is usually described using the basic design charring rate for one-dimensional charring $\beta_{0}$ as reference. This basic design charring rate $\beta_{0}$ differs for different products according to EN 1995-1-2. Increased charring due to corner roundings or gaps can be considered by multiplying the basic design charring rate with coefficients $k_{\mathrm{i}}$ that are greater than 1.0 to determine the notional charring rate $\beta_{\mathrm{n}}$. Recently, a general charring model was proposed by Klippel et al (2016), which is very flexible and can easily be adapted and extended to calculate the char depth of any timber member exposed to fire. The description of this general charring model is shown in Eq 1.

$$
\beta_{\mathrm{n}}=\prod_{k_{\mathrm{i}}} k_{\mathrm{i}} \cdot \beta_{0}
$$

Equation 1 is a general expression to describe the notional charring rate $\beta_{\mathrm{n}}$ for a large range of timber products. This approach is based on a design charring rate $\beta_{0}$ determined in fire resistance tests and specified in EN 1995-1-2. For a specific product, most of the coefficients $k_{\mathrm{i}}$ are equal to 1.0; eg for CLT, only four coefficients are used. In the design model, deterministic values are used.

When wood is exposed to real fires or exposed to controlled conditions represented by fire resistance tests, charring is subject to a variation. Charring models expect that the mean value is reported to assess the basic charring rate $\beta_{0}$. However, the determined values are rarely specified (Lange et al 2014). In the following, the variation of this important value is investigated as CLT as a plane element offers an ideal possibility to investigate the distribution of charring as overlapping heat flow effects at edges of beams or columns do not exist.

In general, charring may be reported as a result measured after the fire test; here, the time between termination and extinguishing of the fire has to be reduced to a minimum to minimize the effects of uncontrolled charring in an undefined environment. Another possibility is to measure charring by means of thermocouples during the test and assess the charring rate by means of the $300^{\circ} \mathrm{C}$ isotherm. In many test reports, a mean value based on thermocouple readings is given. It should be highlighted that the arrangement of the wires or tubes to measure the temperature is crucial for the validity of these measurements. As temperature measurements in a low conductive material such as wood are carried out with conductive metal temperature sensors; these shall be orientated parallel to the isotherms. Deviation may risk falsification of the temperature measurements.

To investigate the variation of charring of CLT, fire resistance tests have been performed on medium-scale CLT and solid timber deck plates (Schmid et al 2017b). The specimens were exposed to standard fire for $60-130 \mathrm{~min}$. The time between the termination of the tests and the extinguishment of the specimens with water was less than 90 s. Subsequently, the char layer was removed and the residual cross-section depth measured manually (see Fig 3). The depth of the residual cross section was measured in a grid of $50 \mathrm{~mm} \times 50 \mathrm{~mm}$ and, thus, the depth of the char layer determined. The char layer depth was then 


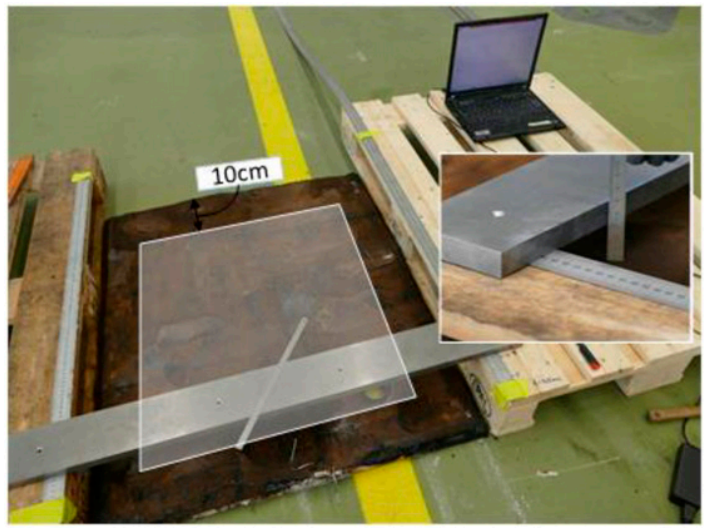

Figure 3. Measuring the residual cross section of the crosslaminated timber specimen by hand.

divided by the time of fire exposure, which gives the one-dimensional charring rate. Figure 4 shows the one-dimensional charring rate; the outer $100 \mathrm{~mm}$ of the CLT panel was not considered to exclude side effects for Test 02 . It can be seen that the charring rate is not constant. Table 2 and Fig 5 show the assessment of the charring rate for all Tests 01-03. A standard deviation for the charring rate of maximum $9 \%$ was determined, which has previously been found in other test series on glued-laminated timber beams as well (Frangi et al 2003). It should be noted that the difference in the residual

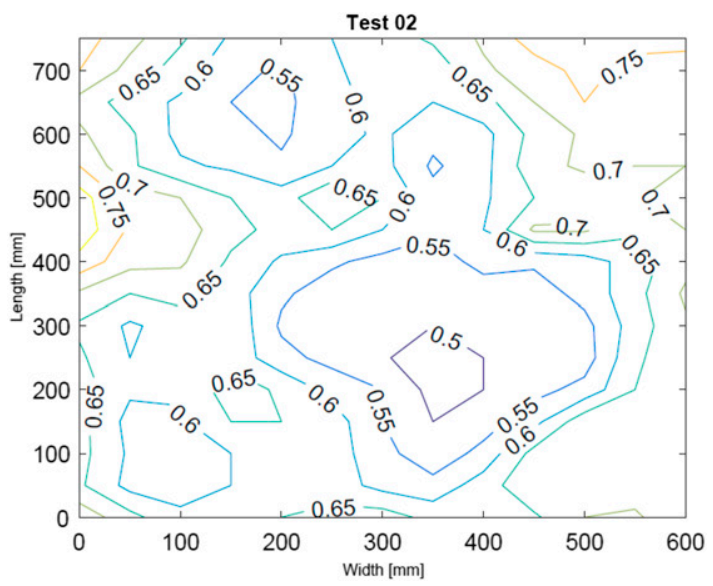

Figure 4. Charring rate of specimen Test 02 based on the measurements of the residual cross section (grid size $50 \mathrm{~mm} \times$ $50 \mathrm{~mm})$. cross-section depth between the mean value and the highest determined char layer depth was $39.6 \mathrm{~mm}$ in the case of Test 02 . The extended fire exposure of $130 \mathrm{~min}$ compared with most of the available test results leads to a considerable difference of the residual cross section and, thus, to the estimation of the load bearing capacity.

\section{Load Bearing Capacity of CLT in Fire}

Using the effective cross-section method, corresponding to fire design of timber beams and columns, a two-step approach is used to determine the load bearing capacity. After the estimation of the residual cross section for a requested time of fire exposure, the load bearing capacity of this residual cross section shall be determined. The effective cross-section method uses a layer with assumed zero strength or stiffness directly beyond the char line to compensate the losses of the residual section due to heat. Using this design method, material properties as at normal condition can be used for further design. Based on simulations, this idea was presented for glulam beams in the $80 \mathrm{~s}$ (Schaffer et al 1986), and the approach applied for CLT members based on testing and simulation was presented later (Schmid et al 2010). Determined depths of the zero-strength layer to compensate strength $\left(d_{0, \mathrm{fm}}\right)$ and stiffness $\left(d_{0, \mathrm{E}}\right)$ losses are presented for a large range of products with corresponding trend lines in Fig 6.

The trend lines in Fig 6 were determined by means of simulations, which were verified with tests. A typical phenomenon corresponding to CLT exposed to fire is falloff of charred layers, ie failure of the adhesive between layers if the bond line reaches a certain temperature, usually the char temperature of $300^{\circ} \mathrm{C}$ (Schaffer et al 1986; EN 1995-1-2). On one hand, the failure leads to increased charring as the virgin wood that comes to be exposed loses the thermal insulation of the charred lamellae. Consequently, its load bearing capacity is reduced faster. On the other hand, the sudden direct exposure after failure of the protective charred lamellae leads to a steep temperature gradient within the virgin wood. As 
Table 2. Evaluation of charring rate.

\begin{tabular}{|c|c|c|c|c|c|c|c|c|c|}
\hline Test & $\begin{array}{r}\text { Time } \\
(\mathrm{min})\end{array}$ & $\underset{(\mathrm{mm} / \mathrm{min})}{\operatorname{Max}}$ & $\begin{array}{c}\text { Min } \\
(\mathrm{mm} / \mathrm{min})\end{array}$ & $\begin{array}{c}\text { Mean } \\
(\mathrm{mm} / \mathrm{min})\end{array}$ & $\begin{array}{c}\text { Standard } \\
\text { deviation }(-)\end{array}$ & $\begin{array}{l}\text { Max. char } \\
\text { depth (mm) }\end{array}$ & $\begin{array}{c}\text { Min. char } \\
\text { depth (mm) }\end{array}$ & $\begin{array}{l}\text { Mean char } \\
\text { depth (mm) }\end{array}$ & $\begin{array}{l}\text { Number of } \\
\text { points }(-)\end{array}$ \\
\hline 01 & 60 & 0.98 & 0.58 & 0.77 & 0.09 & 58.8 & 34.8 & 46.2 & 206 \\
\hline 02 & 120 & 0.98 & 0.46 & 0.65 & 0.09 & 117.6 & 55.2 & 78.0 & 206 \\
\hline 03 & 120 & 1.08 & 0.88 & 1.00 & 0.04 & 129.6 & 105.6 & 120.0 & 206 \\
\hline
\end{tabular}

a result, the weakened depth is reduced and, thus, the zero-strength layer is reduced as well (see Fig 7). In Fig 7, the relative bending moment capacity $M_{\mathrm{fi}} / M_{20^{\circ}}$ over time is used for an example (dashed black curve). Simulations resulted in a zero-strength layer of $11 \mathrm{~mm}$ for these specific CLT panels. As comparison, a curve is shown if Eurocode (EN 1995-1-2 2004) would have been followed, ie $d_{0}=7 \mathrm{~mm}$ would have been applied. The differences between the two result in an overestimation of the fire resistance of about 10 min. As continuous lines, the curves for $M_{\mathrm{fi}} / M_{20^{\circ}}$ in case of the loss of stickability (falloff) of charred layers to the CLT are shown. Although $d_{0}=7 \mathrm{~mm}$ is conservative in that case, a corresponding value to the actual temperature profile within the section would be $4 \mathrm{~mm}$. However, as the loss of stickability cannot be guaranteed, it is

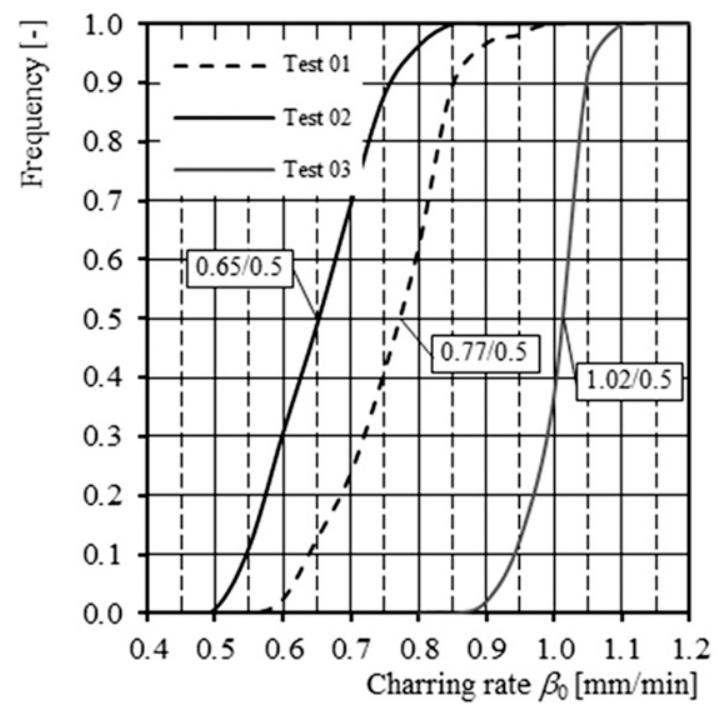

Figure 5. Frequency of one-dimensional charring rate $\beta_{0}$ of three cross-laminated timber (CLT) medium-scale CLT panels tested in a 120-min fire resistance test using EN/ISO standard fire exposure. not recommended to lower the zero-strength layer appropriate for CLT where no falloff of charred lamellae occurs.

\section{PROTECTION BY CLADDINGS}

CLT structures can be protected by claddings to limit fire spread and limit the contribution of CLT to the fire. Protected CLT does not have charring in the beginning of fire. Different charring rates apply depending on whether CLT is initially protected or unprotected from direct fire exposure. Charring starts more slowly behind a protective cladding (Phase 2, Fig 8). When the cladding falls off, charring occurs with a much higher rate than that of initially unprotected wood (Phase 3, Fig 8). The start time of charring $t_{\mathrm{ch}}$ and the falloff time $t_{\mathrm{f}}$ of claddings (see Fig 8) are, therefore, important parameters for the fire safety design of protected CLT structures. These times

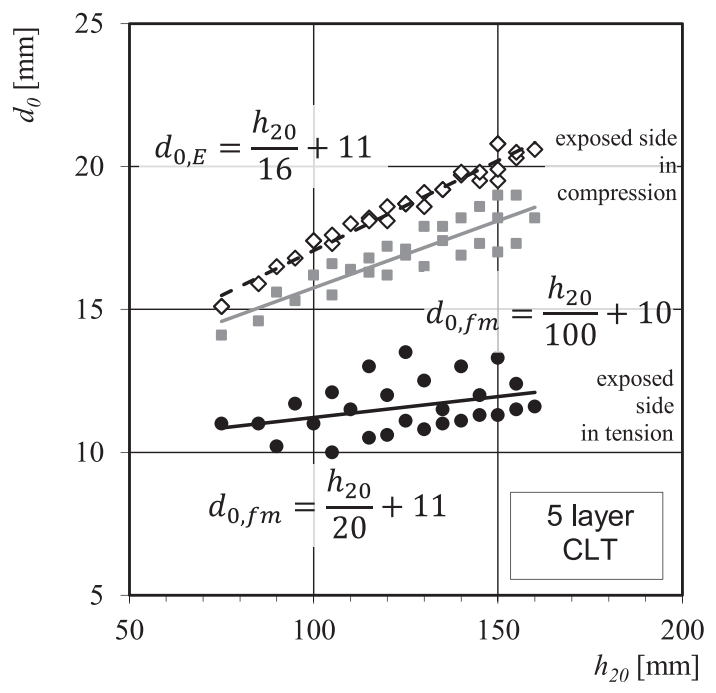

Figure 6. Zero-strength layer for five-layer cross-laminated timber panel. 


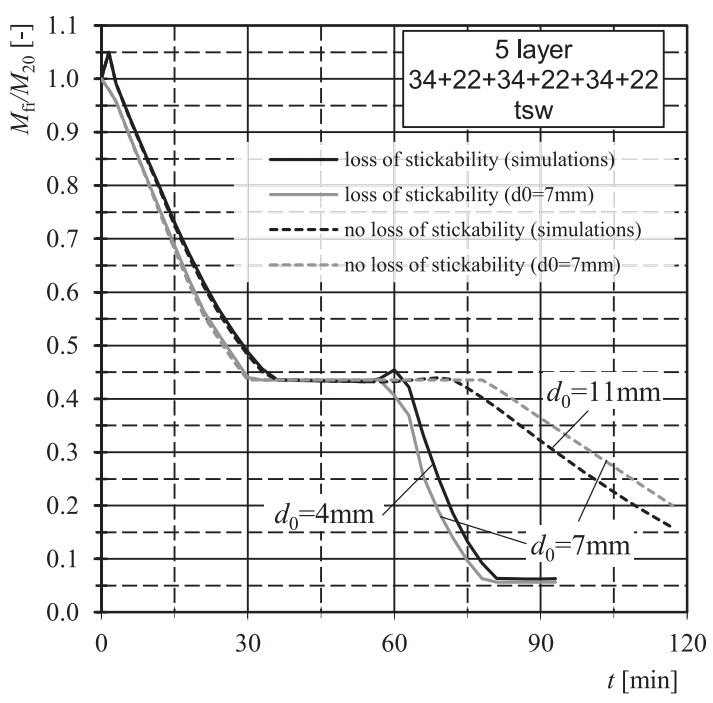

Figure 7. Load bearing capacity vs time of fire exposure for a five-layer cross-laminated timber panel with and without falloff of charred layers (loss of stickability).

depend on thickness, density, and type of protective materials.

In Europe, rules describing protection by commonly used claddings as gypsum plasterboards and wood-based boards are published in Eurocode 5 Part 1-2 and handbooks. Protection provided by other boards and protection systems should be determined by testing. Eurocode 5 is

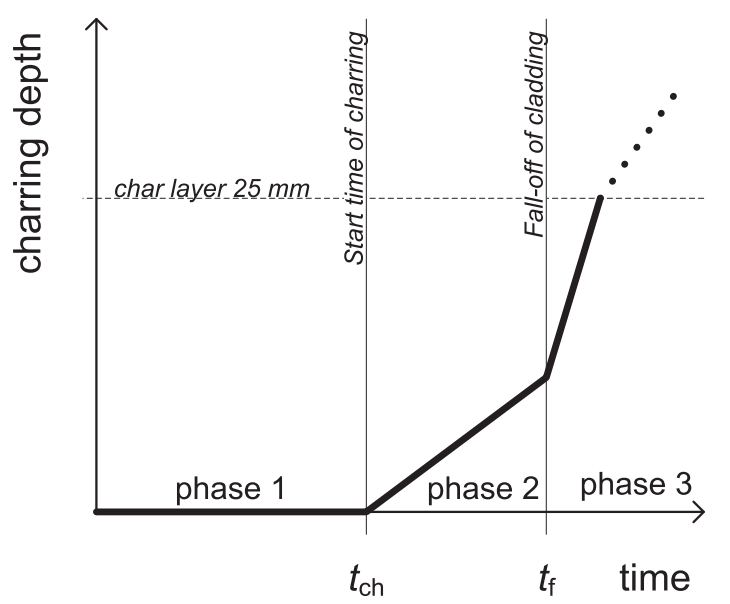

Figure 8. Protection phases for timber member behind the cladding. presently under revision. Revised design rules are planned to be published in 2022 .

\section{Start Time of Charring}

In the revised version of Eurocode 5, the component additive method described in Schleifer (2009) will be used for calculating the start time of charring. The method is based on summing protection times of cladding layers.

$$
t_{\mathrm{ch}}=\sum t_{\mathrm{prot}, \mathrm{i}}
$$

where $\Sigma t_{\text {prot,i }}$ is the sum of protection times of $i$ layers protecting timber members. The protection time of each layer is depending on the thickness and density of the material. The effect of preceding and backing layers of the considered layer are taken into account by position coefficients.

The protection provided by noncombustible panel products depends on several important interrelated properties: the thermal insulation of the board, the ability of the board to remain in place and not disintegrate or fall off after dehydration, the resistance to shrinkage, and the ability of the core material to resist ablation from the fire side during extreme fire exposure. Protection times are also used to take into account the contribution of the materials for the separating function of the construction.

\section{Falloff Time of Protecting Claddings}

Falloff of the board is depending on the placing and length of fasteners and thermal degradation of the board itself. The anchorage length of fasteners in uncharred wood can be easily calculated by using the charring in the protection phase. An anchorage length of $10 \mathrm{~mm}$ in the unburnt wood is the assumed limit to ensure that the board remains in place for the assumed duration of the protection phase. Falloff times due to thermal degradation can vary for different products and within different products of gypsum plasterboards, eg Type F (EN 520), but the 
current standard does not include information on falloff times.

To provide generic data for the gypsum plasterboards, independent of producers, a database of full-scale fire tests with gypsum boards was collected and analyzed (Just et al 2010). The database consists of more than 400 full-scale test results from different fire laboratories, mostly all over Europe. The results in the database are based on visual observations during testing. It is assumed that the recorded failure time is always longer than the real one. This is due to the fact that very seldom, the observer watches through the furnace window and waits for the cladding failure.

Based on the database, conservative generic equations to calculate the falloff time and time to start of charring for gypsum plasterboards and gypsum fibreboards were generated, accounting for different products. The equations were published in the Technical Guideline for Europe (Östman et al 2010).

Single layers of gypsum plasterboards, Type A (not fire rated boards), are assumed not to have a protection phase, see Fig 8 . The start time of charring is considered to be the same as the falloff time of the board. However, for multiple layers of Type A, there is a clear time period between the start of charring and the failure time.

Protection provided by wood-based claddings is based on calculating charring of wooden-based boards. Charring rates differ from the ones of solid wood.

\section{Fire Testing of Protecting Claddings}

Producers of claddings should provide their own values of protection and falloff times. Design parameters for other claddings and also for specific products must be determined by a European standard (prEN 13381-7). It is favorable to determine the protection times of claddings by means of model-scale and full-scale testing. According to prEN 13381-7, falloff times are determined using thermocouples in full-scale fire tests with certain configurations.
A procedure is proposed for the revised Eurocode 5 Part 1-2 for determining falloff times of claddings, based on older full-scale test data, but existing test results should be handled carefully. Older fire test results may be used only if proved that product properties are not changed meanwhile.

\section{K-Classes of Protecting Claddings}

K-classes (EN 14135; EN 13501-2) are used as protection when charring should be avoided, ie mainly for load bearing structures in some countries. K-classes can be counted as start time of charring containing extra safety margin. K-classes are defined for 10-, 30-, or 60-min protection.

\section{FIRE SAFE DETAILING FOR CLT STRUCTURES}

A main principle within the European fire safety regulation of buildings is the limitation of the spread of fire and smoke to other compartments and neighboring buildings. For this fundamental requirement, the structural stability and the separating function of wall and floor elements represent the most essential capacities in the case of fire. Both criteria can be assessed either based on standardized fire tests, as listed in EN 13501-2 or by design standards, such as EN 1995-1-2 or additional technical guidelines (Östman et al 2010). These methods normally do not, or just to a low extent, take into account any joints and junctions to neighboring elements or the influence of mounting parts and penetrations of service installations.

In general, for all constructions including CLT, three flame spread paths can be identified, as schematically depicted in Fig 9. These potential passes must be taken into account within the design process to ensure an overall fire safety:

I. joints in and between prefabricated plane elements

II. joints in corner connections to other building parts

III. joints resulting from service installations and penetrations. 


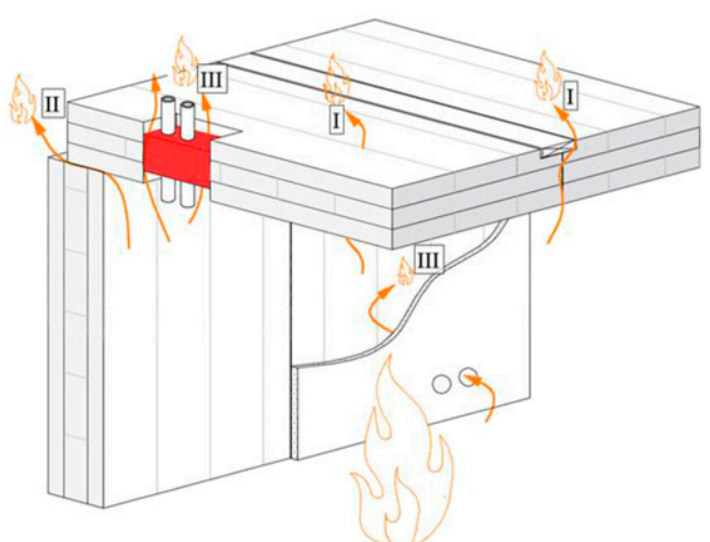

Figure 9. Flame spread paths for buildings using crosslaminated timber.

\section{In-Plane Joints of CLT Elements}

Several research projects and producer-specific fire tests in recent years dealt with the assessment of CLT elements with respect to load bearing and separating function up to $90 \mathrm{~min}$. In addition, analytical-based assessment methods (Östman et al 2010) can be used to design CLT elements when exposed to standard fire.

Besides the plane element itself and associated joints, standard fire tests can consider the influence of joints between CLT elements (see Fig 9, path I). To evaluate the performance of in-plane connections, the separating insulation integrity (EI) criteria are used to avoid that the temperature at the unexposed side increase more than $180^{\circ} \mathrm{C}$ in relation to ambient conditions and that hot gases ignite objects on the unexposed side. Some studies also investigate the smoke tightness as a third criterion that is not standardized so far.

The existing tests show that joints may lower the fire resistance and influence the smoke tightness in a negative way. Gaps resulting from fabrication inaccuracy or construction tolerances allow hot gases and smoke to pass through at overpressure conditions under fire exposure and reduce the fire resistance for the entire structure (McGregor 2013). In this context, butt connections should be prevented. Joints with splines or step joints between the elements show sufficient fire resistance in comparison with the plane CLT elements, if the remaining cross section covered by an interior double spline, a step joint or an exterior spline is at least $2 \mathrm{~cm}$ (Teibinger et al 2013) (see Fig 10). To improve the fire resistance and also smoke tightness, the use of an elastic joint sealant on both sides of the elements or the implementation and compression of a flexible mineral wool stripe is recommended (Hosser et al 2008).

\section{Corner Connections of CLT}

Also for corner connections, the spread of fire and smoke to other fire compartments must be prevented. However, no standardized test method exists at the moment to assess the performance of fireexposed corner junctions. In general, the conducted tests show that the charring depths within the corner were less than the spatial elements (see Fig 10). This aspect can be explained with the lower heat flux density at inside corners. In CLT wall to floor connections, elastomer vibration absorbers are often used. Fire tests with lined CLT wall elements and unprotected floors showed that these absorbers combined with a practical air tight sealing do not negatively influence the overall fire resistance (Teibinger 2011; Merk et al 2014).

\section{Service Penetrations and Mounting Parts}

Until today, tested and approved solutions for fire safe service installations in timber structures are rare and only slowly reaching the market, even though they can be tested in accordance with EN 1366 series. Fire tests with sealing systems for cables and service pipes in CLT elements show that intumescent-based systems can fulfill the requirements on separation function for more than $90 \mathrm{~min}$ (Östman et al 2010; Teibinger et al 2012). As a main concept to install multipenetration sealing systems, such as mineral wool boards, a noncombustible lining of the reveal area over the entire thickness of the separating element is recommended (Östman et al 2010) (see Fig 10). For the installation of sockets and recessed electrical boxes penetrating a protective lining of CLT elements, also 


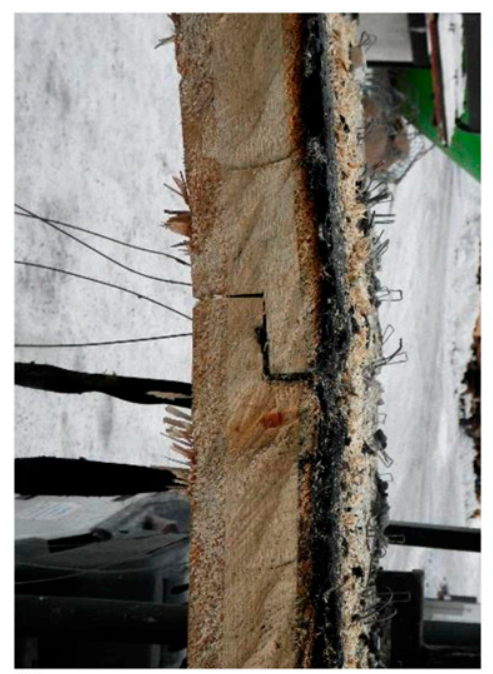

(a)

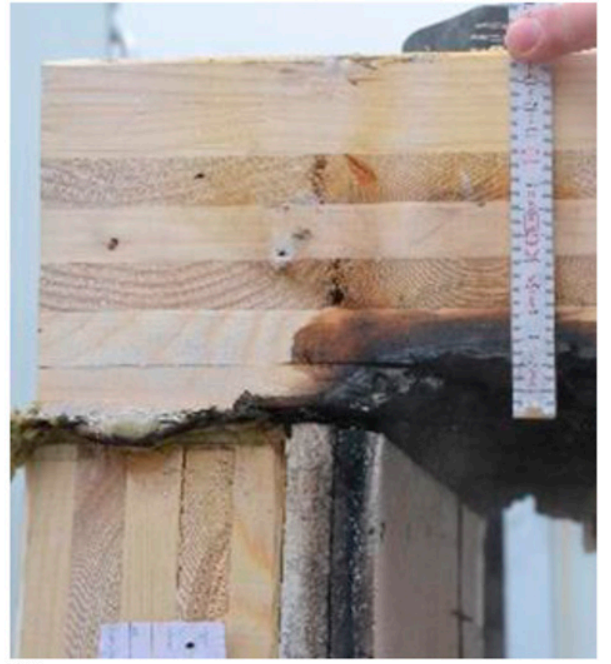

(b)

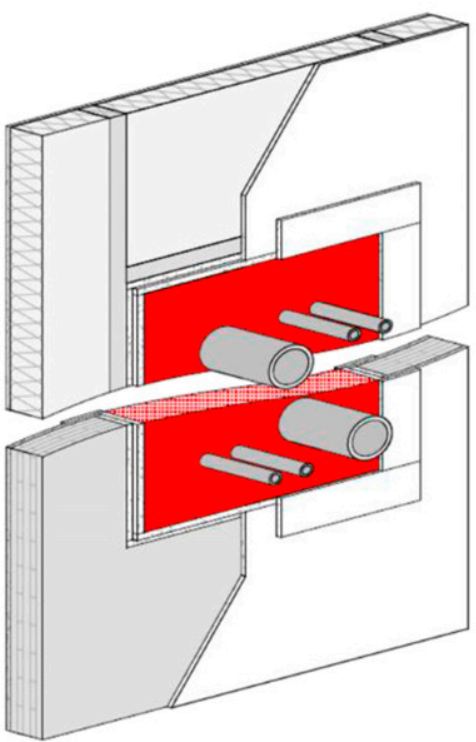

(c)

Figure 10. Fire safe detailing, (a) step joint in cross-laminated timber element, (b) wall-floor connection with mineral compressed wool sealing, (c) installed penetration sealing system with lined reveal area.

an intumescent coating in and around the penetrated area can be recommended to protect the timber from ignition.

\section{PERFORMANCE-BASED DESIGN}

In the field of fire safety engineering, performancebased design methods are increasingly used to demonstrate that building designs are safe. However, performance-based design is not commonly used for the design of timber structures as there are not many relevant assessment methods available (Östman et al 2010). For assessment whether the design of a building meets certain criteria, design fires based on the building design are needed.

As timber is a combustible material, it may contribute to the fuel of a fire. Therefore, it is not possible to use general design fires for fire 
compartments with noncombustible materials, especially if large surfaces of timber are exposed. Lack of knowledge about the contribution of CLT to a fire was previously identified as one of the main knowledge gaps for the realization of tall timber buildings (Gerard et al 2013) and existing knowledge has been compiled (Brandon and Östman 2017). Pragmatic zone models were also developed that make predictions of the fire duration, and fire temperatures of a compartment fire, based on its dimensions, ventilation conditions, and amount of timber exposed and protected (Hopkin et al 2011; Brandon 2016).

\section{Postflash Design Fires for Compartments with Exposed Timber}

A first model to include the contribution of exposed CLT, which consisted of a simple singlezone model used in combination with heat transfer models for the compartment boundaries, was reported (Brandon 2016). However, as stated, improvements were necessary regarding temperature predictions within the timber so that such a model can function well in the decay phase. An improvement of the model is described by Hopkin et al (2011) and uses a thermal property framework that is effective to predict temperatures in parametric fires, with a decay phase.

Zone models are simple and pragmatic means of quantifying the variability of gas temperature as a function of time in small enclosures, relying on a straightforward conserving of mass and energy. For structural fire engineering purposes, where postflashover behavior is often the phase of interest, a single-zone model is often adequate. Energy is introduced within the control volume, typically, via the heat release rate of the variable fire load, eg the furniture within an apartment. Losses are by way of convective and radiative components to the atmosphere (via openings), and heat transfer to the enclosure. Any remaining energy is stored within the gas, leading to an increase in temperature.
The zone model concepts are well developed and subject to extensive coverage in the literature (Wickström 2016). For the quintessential and common single-zone model, the derivation of the compartment time-temperature relation relies on the resolution of a straightforward energy balance. In a one-zone model, the heat stored in the gasses of the compartment is equal to the difference between the heat released within the compartment and the heat lost through openings and through the walls, floor, and ceiling. By assuming that the gas temperature is homogeneous in a postflashover compartment fire, which is reasonable for small compartments, the gas temperature can be calculated from the heat release rate of the variable fuel load. According to EN 1991-1-2, homogeneous temperature in compartments can be assumed for compartments with floor areas up to $500 \mathrm{~m}^{2}$.

Zone models require knowledge of the heat release rate of the variable fire load. Pragmatic relationships to predict the heat release rate of the variable fire load in postflashover fires in apartment buildings were given by Hopkin et al (2017) and validated using experimental results of fullscale compartment fire tests in which only the variable fire load combusted.

In the existing models that include the contribution of CLT to the fuel load of the fire (Hopkin et al 2011; Brandon 2016), the heat release rate of solely the timber is determined from a predicted charring rate of exposed or protected timber, as shown in Fig 11. The studies showed that adding the heat release rate of CLT to the heat release rate of the variable fire load for the full fire duration leads to reasonable predictions of the fire temperatures and fire duration. The charring rates are determined using one-dimensional heat transfer models, which calculate the temperature profile in the wooden boundaries. As the timber is completely turned into char at approximately $300^{\circ} \mathrm{C}$, the predicted temperature profile in the timber throughout the duration of the fire can be used to estimate the charring rate. Schmid et al (2016) showed that there is a practically constant ratio between charring rate and heat release rate. This ratio is used to determine the heat release rate of CLT from the calculated charring rates. 


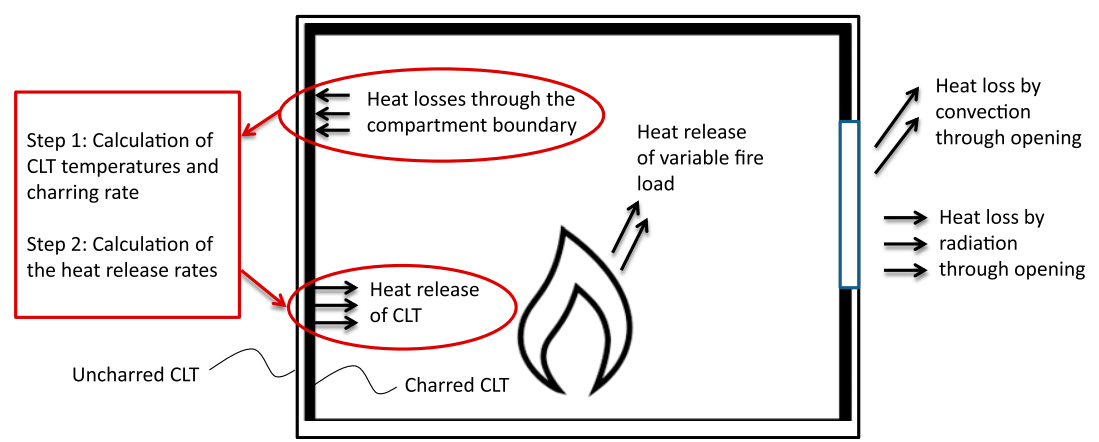

Figure 11. Schematic representation of a single-zone model that includes the contribution of cross-laminated timber (CLT) to the fire load.

\section{RESEARCH NEEDS}

With regard to the load bearing capacity of CLT in fire, the model for protected timber members according to Eurocode 5 can be used to determine the residual cross section of CLT considering possible local falling off of charred layers during fire. However, the European model seems to deliver very conservative results for initially protected CLT panels by (ie gypsum plaster or gypsum fibreboards) and a fire resistance of more than $90 \mathrm{~min}$. It was also concluded in the past that the accuracy of the char depth predictions decreases with increasing area of exposed CLT. Ongoing research aims to improve predictions for compartment fires involving falloff of charred layers of CLT or falloff of fire-protective cladding.

In addition, further research on the determination of the zero-strength layer as used in Eurocode 5 needs to be conducted to ensure a safe and easy-to-use fire design method of CLT and equally provide an economically and ecologically worthwhile use of the product.

Detailing such as connections and joints, and service installations all need more research.

\section{REFERENCES}

Babrauskas V (2005) Charring rate of wood as a tool for fire investigations. Fire Saf J 40(6):528-554.

Brandon D (2016) Practical method to determine the contribution of structural timber to the heat release rate and fire temperature of post-flashover compartment fires. SPTechnical Research Institute of Sweden, SP Rapport 2016: 68, Stockholm, Sweden.
Brandon D and Östman B (2017) Fire Safety Challenges of Tall Wood Buildings - Phase 2: Task 1 - Literature Review. Report FPRF-2016-22, Fire Protection Research Foundation, NFPA, USA.

Hopkin D, Anastov S, Brandon D (2017) Reviewing the veracity of a zone-model-based-approach for the assessment of enclosures formed of exposed CLT. In M Gillie, Y Wang Applications of Fire Engineering - proceedings of the International Conference of Applications of Structural Fire Engineering, Manchester, UK, September 2017, CRC Press Taylor \& Francis Group, London, pp. 151-160.

COMMISSION DELEGATED REGULATION (EU) 2017/ 2293 on the conditions for classification, without testing, of cross laminated timber products covered by the harmonised standard EN 16351 and laminated veneer lumber products covered by the harmonised standard EN 14374 with regard to their reaction to fire. Official Journal of the European Union 13.12.2017. European Commission, Brussels.

CONSTRUCT 01/491 rev 3 (2004) Classification of products of known and stable performance-Procedural aspects. European Commission, Brussels.

Construction Products Regulation (CPR) (2013) Official Journal Council Directive 89/106/EEC OJ L 88 of April 4, 2011. European Commission, Brussels.

EN 520:2004. Gypsum plasterboards-Definitions, requirements and test methods. European Standard. CEN_European Committee for Standardization, Brussels.

EN 1366 series. Fire resistance tests for service installations. European Standard. CEN_European Committee for Standardization, Brussels.

EN 1991-1-2:2002. Eurocode 1. Actions on structures-Part 1-2: General actions-Actions on structures exposed to fire. European Standard. CEN-European Committee for Standardization, Brussels.

EN 1995-1-2:2004. Eurocode 5. Design of timber structures-Part 1-2: General-Structural fire design. European Standard. CEN-European Committee for Standardization, Brussels. 
prEN 13381-7:2017. Test methods for determining the contribution to the fire resistance of structural members. Part 7: Applied protection to timber members. Draft European Standard. CEN-European committee for standardization, Brussels

EN 13501-1:2009. Fire classification of construction products and building elements-Part 1: Classification using test data from reaction-to-fire tests. European Standard. CEN-European committee for standardization, Brussels.

EN 13501-2:2009. Fire classification of construction products and building elements-Part 2: Classification using data from fire resistance tests, excluding ventilation services. European Standard. CEN European Committee for Standardization, Brussels.

EN 14135:2005. Coverings-Determination of fire protection ability. CEN European Standard. European Committee for Standardization, Brussels.

prEN 16351. Timber structures-Cross laminated timber-Requirements. Draft European Standard. CEN, European Committee for Standardization, Brussels, 2015 (final version expected in 2019).

EN 16755:2017. Durability of reaction to fire performance of FRT wood-based products in interior and exterior end-use applications. European Standard. CEN-European Committee for Standardization, Brussels.

Frangi A, Fontana M (2003) Charring rates and temperature profiles of wood sections. Fire Mater 27(2):91-102.

Gerard R, Barber D, Wolski A (2013) Fire safety challenges of tall wood buildings. Fire Protection Research Foundation (FPRF), Quincy, MA.

Hakkarainen T (2002) Post-flashover fires in light and heavy timber construction compartments. J Fire Sci 20:133-175.

Hopkin D, El-Rimawi J, Silberschmidt V, Lennon T (2011) An effective thermal property framework for softwood in parametric design fires: Comparison of the Eurocode 5 parametric charring approach and advanced calculation models. Constr Build Mater 25(5):2584-2595.

Hosser D, Kampmeier B (2008) Bewertung des Brandverhaltens unbekleideter flächiger massiver Holzbauteile im Hinblick auf die Einsatzmöglichkeiten im mehrgeschossigen Holzbau unter Berücksichtigung des geltenden nationalen Sicherheitsniveaus sowie der DIN EN 1995-1-2. Forschungsauftrag der deutschen Gesellschaft für Holzforschung. Braunschweig, Deutschland.

Just A, Schmid J, König J (2010) Failure times of gypsum boards. In Proceedings of the 6th International Conference Structures in Fire: Structures in Fire, East Lansing, MI, USA, 2.-4.6.2010. DesTech Publications Inc, 593-601.

Klippel M, Schmid J, Frangi A (2016) Fire design of CLT. In Proc. Joint Conference of COST Actions FP1402 \& FP1404 Cross Laminated Timber: A Competitive Wood Product for Visionary and Fire Safe Buildings. March 10, 2016. KTH Royal Institute of Technology, Stockholm, Sweden.

Lange D, Boström L, Schmid J, Albrektsson J (2014) The influence of parametric fire scenarios on structural timber performance and reliability. SP-Technical Research Institute of Sweden, Boras, Sweden. SP Report 2014:35.
LeVan S, Holmes CA (1986) Effectiveness of fire-retardant treatments for shingles after 10 years of outdoor weathering. FPL Forest Products Laboratory, Madison, WI. Research Paper FPL 474.

McGregor CJ (2013) Contribution of cross laminated timber panels to fires. Department of Civil and Environmental Engineering, Carleton University, Ottawa, ON, Canada.

Medina Hevia AR (2014) Fire resistance of partially protected cross-laminated timber rooms. Master thesis, Department of Civil and Environmental Engineering Carleton University, Ottawa, ON, Canada.

Merk M, Werther N, Gräfe M, Fülle C, Leopold N, Sprinz D, Busch M, Brunn M (2014) Erarbeitung weiterführender Konstruktionsregeln/-details für mehrgeschossige Gebäude in Holzbauweise der Gebäudeklasse 4. Fraunhofer IRB Verlag, Stuttgart, Deutschland.

Nussbaum RM (1988) The effect of low concentration fire retardant impregnations on wood charring rate and char yield. J Fire Sci 6:290-307.

Östman B, Voss A, Hughes A, Hovde PJ, Grexa O (2001) Durability of fire retardant treated wood products at humid and exterior conditions-Review of literature. Fire Mater 25:95-104.

Östman B, Mikkola E (2010) European classes for the reaction to fire performance of wood-based panels. Fire Mater 34:315-332.

Östman B, Mikkola E, Stein R, Frangi A, König J, Dhima D, Hakkarainen T, Bregulla J (2010) Fire safety in timber buildings-European Guideline. SP-Technical Research Institute of Sweden. SP Report 2010:19.

Östman B, Mikkola E (2010) European classes for the reaction to fire performance of wood-based panels. Fire Mater 34:315-332.

Östman B, Tsantaridis L (2017) Durability of the reaction to fire performance of fire retardant treated wood products in exterior applications-A ten years report. Int Wood Prod J 8(2):94-100.

Schaffer EL, Marx CM, Bender DA, Woeste FE (1986) Strength validation and fire endurance of glued-laminated timber beams. United States Department of Agriculture, Forest Products Laboratory, Research Paper FPL 467, Madison, WI.

Schleifer V (2009) Zum Verhalten von raumabschliessenden mehrschichtigen Holzbauteilen im Brandfall. PhD Thesis No. 18156, ETH Zürich, Zürich, Switzerland.

Schmid J, König J, Köhler J (2010) Fire-exposed crosslaminated timber-Modelling and tests. In Conference Proceedings $11^{\text {th }}$ World Conference on Timber Engineering (WCTE 2010), 20-24 June 2010, Trentino, Italy.

Schmid J, Brandon D, Santomaso A, Wickström U, Frangi A (2016) Timber under real fire conditions-The influence of oxygen content and gas velocity on the charring behaviour. In Proc. 9th International Conference on Structures in Fire Conference, Princeton, NJ 8-10 June, 2016.

Schmid J, Klippel M, Daniel B, Werther N (2017a) Thermal exposure of wood in standard fire tests and post-flash over 
fires. Technical Note. Fire Mater, Accepted for publication February 2018.

Schmid J, Klippel M, Fahrni R, Frangi A (2017b) Fire resistance tests of cross-laminated timber and solid timber deck plates, Report Fr-2017-03. ETH Zürich, Zürich, Switzerland.

Teibinger M (2011) Brandschutz im Detail. Holzbau - die neue quadriga (4), 39-43.
Teibinger M, Matzinger I (2012) Brandabschottung im Holzbau. Holzforschung, Austria.

Teibinger M, Matzinger I (2013) Construction with CrossLaminated Timber in Multi-Storey Buildings-Focus on Building Physics. Holzforschung, Austria.

Wickström U (2016) Temperature Calculation in Fire Safety Engineering, pp 153-171. Springer International Publishing Switzerland. 